\title{
Neo-Realist Paradigm and the Fragile State of Regional Cooperation in South Asia:
}

\section{Prospects and Challenges}

\author{
* Mr. Saqib Ullah Khan, PhD Scholar (Corresponding Author) \\ ** Ms. Sabira Iqbal, Lecturer \\ *** Mr. Atta Ullah Jan, PhD Scholar
}

\begin{abstract}

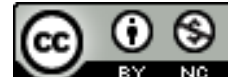

Regionalism is a process of regional cooperation amongst the countries sharing a common border, common values, homogeneity of culture, and common vested interests. While the western world adopted this paradigm early after World War II in the form of the EU, South Asian Region is still deprived of such models. The establishment of SAARC in 1985 by the efforts of the late Bangladeshi President Zia-ur-Rahman although raised certain hopes of regional connectivity in South Asia still the fate of this region lingers in the sky. While using secondary sources of data collection, this paper tries to attempt the underlying challenges and the palpable prospects responsible for the better integration of this region. It further analyses the failed regional cooperation and the role of India under the assumption of the Neo-Realist Paradigm of Kenneth Waltz that emerged in late 1970.
\end{abstract}

Keywords: $\quad$ Regionalism, World War II, South Asia, Neo-Realist, Kenneth Waltz

\section{Introduction}

Regionalism is generally a phenomenon that was early adopted in the 1950s by Western Europe with the establishment of the European Community later on the European Union in 1957 (Garavini, 2012). Here the process gets accomplished in the case of political, social, and economic integration. They established an open market economy, cooperation in the field of technology, common currency, common security, etc. The latter inspired by the idea came in the 1960s in the form of the Association of Southeast Asian Nations (Acharya, 1992). The ASEAN currently holds certain well-established communities in the form of ASEAN Cultural Community, ASEAN Security Community, and ASEAN Economic Community with some other setup that fully endorses the common cause of cooperation. All these regional blocks emerged in the first wave of regionalism while the second wave observed the remaining organization after the 1980s that includes SAARC (1985), North American Free Trade Agreement (1994), and African Union (2002), (Telò, 2007).

Regionalism is a process of regional integration among states, located in a specific geographical area, based on their cultural identity and the parallel idea of collective actions expressed by institutional mechanisms. The process entails a degree of intentionality as states and other stakeholders take on to collaborate in certain areas essentially political collaboration. In the case of South Asia, the process is the same as formal, driven by policy, and above all a top-down approach. Correspondingly, the factor of the formation of the institution is alike to the EU and ASEAN where several heads and the high official came in contact for the desired goal of institutionalization. As the formation of SAARC being a block for regional cooperation achieved counted successes in fields like Social collaboration, technological interchanges, and some trade-related purposes. But contrary to the EU, and ASEAN models of collaboration, SAARC could not develop a pleasurable environment amongst Asian countries when it comes to political collaboration as well as security. Here it was the absence of a common threat or war as a region that could have shaken Asian countries to come close together in terms of security and politics (Christensen, 2011). It was the USSR threat for ASEAN and the Nazi's Germany for EU that united the community close together in terms of politics, economics, and security.

SAARC was established in 1985 by the scheme of late President Zia-ur-Rehman of Bangladesh. At the time it was more astonishing because the move while on the one hand initiated by

\footnotetext{
* Pakistan Study Centre, University of Peshawar Email: saquibwazir@gmail.com

** Pakistan Studies, DIPS, KUST

*** Pakistan Study Centre, University of Peshawar
} 
the smaller countries besides hesitantly adopted by the larger members of the region both India and Pakistan. The motivations behind the scheme were formally based upon the idea of Cooperation, peace, and integrity of the South Asian region ${ }^{7}$ but what the fragile history of the regional Cooperation reveals since the formation of SAARC is that it was the fear and distrust of Regional Hegemonic India on behalf of which smaller states prompted towards such arrangement. Moreover, the viability of SARRC as a regional bloc for cooperation was extensively hampered by the unwillingness of the states (Yadav, 2010). It can be tested from the fact that while the other regional blocks of the world such as the EU and ASEAN, successfully achieved the desired goals of economic, social, and political integration in this ongoing process of Regional cooperation instead of the historical rivalries, and heterogeneities, South Asian Region still depicts a worse image of Regional integration.

In South Asia where the smaller states motivated by the common issues of poor cross-border trade, climatic threats, and poor technological development push forward for the formation of SAARC as a regional body thus qualifies the first round. But when it comes to the second round of this process that includes collaboration in terms of politics, security, common free-market economy like ASEAN, and others, it failed down. The failure of this round while on the one hand is subjected to the suspic ions of the SAARC smaller member states besides it mainly contributed by the larger states due to their hegemonic ambitions in the region.

This paper explains the fragile state of cooperation in the South Asian region in the light of the Noe-Realist concepts like hegemonic theory, Relative gain theory, and Power Asymmetry with a special focus on India's rule as a SAARC member.

\section{Aims and Objectives}

This attempt has been made to investigate the underlying causes of poor regional cooperation in South Asia with special reference to SAARC as the sole regional block in the region. It also aims to identify the palpable challenges due to which SAARC has not yet achieved its objectives like other regional blocks. Apart from this, it also focuses on the possible remedies and prospects that could enhance regional cooperation in this region.

\section{Research Methodology}

This research is quantitative cum explanatory in nature while mostly relying on secondary sources of data collection. These sources include various websites, journal articles, dissertations, newspapers, books, websites, think-tanks, opinions, and magazines.

\section{The ore tical Frame work}

The Neo-Realist paradigm emerged in the late 1970s outlined by Kenneth Waltz in his book "Theory of international politics" (Quinn \& Gibson, 2017). He made a significant explanation to the international relation on three broad levels including domestic, national, and international level. Generally, this paradigm holds the same premises of classical realism where the state is the principal actor and stakeholder in international affairs. It claims the national interests come first and the world is anarchic as there is no divine power functioning successfully to control the conduct of the state (Bhasin, 2008). Those states which are powerful and strong incline to tail the relative gain from their counterparts' weaker states. It contends further that powerful states posed hegemonic postures that addressed by the weaker states in the form of balancing mechanism in this anarchic world (Paul, Wirtz, \& Fortmann, 2004).

In the South Asian Region, it is the Indian hegemonic role towards other smaller states of the region that match the above premises of the Neo-realist paradigm of the anarchistic environment of international relations (Karim, 2014). India is the key regional power that holds a dominant position in this region by gigantic demographic figures, geography, tactical position, gigantic conventional military force, and huge reserves of natural resources with advanced technology. This dominancy led her to the aspiration as not only the sole commander of the region but to dominate the regional affairs single-handedly to ensure stability according to Hegemonic Stability Theory (Shambaugh \& Yahuda, 2014).

In the case of SAARC where India accepted the proposal besides she always inclines to pose her hegemonic nature towards smaller states. The organization was primarily based upon the principle of regional cooperation, peace and stability, and mutual coexistence but when it came to the SAARC Charter she refutes to mandate SAARC on two grounds including bilateral political issues and the principle of unanimity. This decision provided her advantageous position to facade hegemonic 
postures over smaller states on bilateral level rather than multilateral platform due to power asymmetry which resembles the core assumption of the neorealist theory that the exercise of dominant postures by the big powers over the smaller state is a constant reality of the anarchic international structure. Alongside, the principle of unanimity permanently blocked the entrance of any such power like China that may could lousy her position in SAARC. It was only in 2007 that Afghanistan as the eight-member of SAARC was raised to the position of permanent status through a resolution initiated by India on the SAARC platform. Here it was the interests of access to Central Asian resources that prompted India to include Afghanistan as a SAARC member country that resembles the concept of neorealist perspective in which interests of a state are considered above all.

It is preferred that the neorealist concept of hegemony does not apply to the South Asian region because Pakistan is a counterbalance to Indian military might but in the case of Economic power, advanced technology, stable polity, and blesses of geography, she still observes asymmetric position. This asymmetric of India over the remaining states in the region not only reveals imbalances but also created a suspicious environment. On bilateral or multilateral initiatives, smaller countries of the region always remained doubtful about Indian polic ies. As a major regional power, with a vision of securing international status, India always tends to project a big brother attitude towards her neighbors. Furthermore, the Indian nature can be better exemplified from the Indra Doctrine and Kautalian tradition of thinking which consider India an uncontested regional hegemonic power and the next-door neighboring countries as her "Ari" or the enemy (Karim, 2014). All these gestures of India not only hampered the already efforts in the form of SAARC but also pose a great challenge to the vast interest of the remaining Asian countries.

Moreover, SAARC is the only better opportunity for regional cooperation in the South Asian region that can bring peace and prosperity to the region. But here India does not permit to bring bilateral issues on the platform without which regional cooperation is a nightmare. She could not pay alike rule in SAARC as being the regional power. The SAARC functionality was repeatedly affected by the Indian hegemonic postures. From 1985 till 2017, a total of nine SAARC Summits have been postponed due to the refusal of the member states to join the summits. Six of these eight summits were postponed due to India's refusal to join it. Besides she went for several regional sub-structures with few smaller countries than SAARC like BIMSTC, BCIM, and SASEC that once again shows her hegemonic ambitions and attitude towards this region. Such types of sub-regional initiatives by India, while not preferring SAFTA initiated in 2004 under SAARC for intra-regional trade made it clear that she never wanted to promote cooperation among Asian countries. It can also be judged from the recent data that instead of such efforts as SAFTA and SAPTA, the South Asian intra-regional trade was barely $5 \%$ of the total trade volume of the regional member's countries compared to the EU, and ASEAN of $60 \%$ and 25\% respectively (Murshed, 2021). While being the regional economy she always been the most closed economy and maintained a large gap of trade volume among her and her neighbors by imposing a high tariff, quota, and other trade barriers (Irwin, 2011).

The contextualization of the neorealist perspective while linking it to the Indian rule in the regional cooperation framework clearly shows the underlying cause of the failure of the regional cooperation in South Asia. It pretends that India never subjected herself to the principle of equality while posing all the times' hegemonic gestures in the South Asian region. On the one hand, she tried to maintain regional hegemonic structures through extending certain strategies besides she awesomely maintained a nominal structure for cooperation in this region. It directs a vision for smaller Asian countries to devise a policy by which the palpable challenges can be fully minimized while exploiting all the opportunities that favor regional cooperation in South Asia without relying on India. Following are some of the pooled prospects and challenges that equally affect SAARC member countries for regional cooperation in South Asia.

\section{Challenges}

\section{Inter-State Conflicts}

South Asia is one of the most complex regions in terms of security in the world primarily since most of the Asian countries are engulfed with varying degrees of conflicts and disputes (Bandara, \& Cai, 2014). Inter-state conflicts in this region probably the highest compared to any other regional blocs. These inter-state conflicts include territorial disputes, Cross-border terrorism, conflicts over natural resources, and immigrants, refuges-related conflicts. The given table shows all these conflicts in minor detail with countries involved in these disputes. 


\begin{tabular}{|c|c|c|}
\hline $\begin{array}{l}\text { MEMBER } \\
\text { COUNTRIES }\end{array}$ & $\begin{array}{lll}\text { NATURE } & \text { OF } & \text { THE } \\
\text { CONFLICT } & & \end{array}$ & CONFLICT \\
\hline INDIA-PAKISTAN & TERRITORIAL & $\begin{array}{l}\text { DISPUTE OVER KASHMIR, SIACHEN } \\
\text { GLACIERS, SIR CREEK, AND KARGIL }\end{array}$ \\
\hline $\begin{array}{l}\text { AFGHA NISTAN- } \\
\text { PAKISTAN }\end{array}$ & TERRITORIAL & ISSUE OF DURAND LINE \\
\hline INDO-NEPA L & TERRITORIAL & $\begin{array}{l}\text { TERRITORIAL } \\
\text { OVER KALAPANI AND SUSTA AREAS. }\end{array}$ \\
\hline $\begin{array}{l}\text { INDIA- } \\
\text { BANGLADESH }\end{array}$ & $\begin{array}{l}\text { IMMIGRANTS } \\
\text { REFUGEES }\end{array}$ & $\begin{array}{l}\text { IMMIGRATION OF BANGLADESHI } \\
\text { INTO INDIA }\end{array}$ \\
\hline NEPAL-BHUTAN & $\begin{array}{l}\text { IMMIGRANTS } \\
\text { REFUGEES }\end{array}$ & $\begin{array}{l}\text { OVER REPATRIATION } \\
\text { BHUTANESE } \\
\text { REFUGES IN NEPAL. }\end{array}$ \\
\hline INDIA-PAKISTAN & NATURAL RESOURCES & BAGLIHAR DAM \\
\hline $\begin{array}{l}\text { INDIA- } \\
\text { BANGLADESH }\end{array}$ & NATURAL RESOURCES & $\begin{array}{l}\text { CONSTRUCTION OF } \\
\text { BARRAGE ON GANGA'S RIVER }\end{array}$ \\
\hline INDIA-PAKISTAN & $\begin{array}{l}\text { CROSS - BORDER } \\
\text { TERRORISM }\end{array}$ & $\begin{array}{l}\text { BOTH COUNTRIES BLAME ONE } \\
\text { ANOTHER FOR SUPPORTING CROS- } \\
\text { BORDER TER TISM ANIS AND } \\
\text { INSURGENCIES IN THEIR COUNTRY. }\end{array}$ \\
\hline INDIA-SRILANKA & $\begin{array}{l}\text { CROSS - BORDER } \\
\text { TERRORISM }\end{array}$ & $\begin{array}{l}\text { SRILANKA BLAMES INDIA FOR } \\
\text { SUPPORTING TAMIL REBELLION IN } \\
\text { HER COUNTRY. }\end{array}$ \\
\hline
\end{tabular}

All the above-tabled conflicts not only affected regional cooperation throughout the last few decades but also led to a constant rise in the military expenditure that side-tracked the region from a healthy to an unhealthy environment for human development and made it unfavorable for peaceful coexistence among South Asian states. It is the continuity of exporting modern weapons, and arms from France, China, and the USA by the South Asian States that critically shifted precious financial resources from cooperation to competition.

Alongside, smaller neighbors of India were initially enthusiastic in the formation of SAARC as a bloc for regional cooperation in South Asia but they resisted SAARC's practices for the last several decades. The major reason is the fear of Indian hegemonic strategies and the subsequent interdependence that may cost smaller states in the form of eradication of their sovereignty, and political autonomy. In the case of India-Pakistan, it is the uneasy relations and Ad-hoc policies that hampered SAARC as a viable setup for regional cooperation (Singh, 2016). All the remaining states of Asia are adamant about not giving primacy to any sort of cooperation till the time the bilateral issues are not solved. It can be argued that until and unless the political issues are not properly addressed, cooperation in South Asia cannot be realized fully

\section{Intra-State Issues}

The intra-state issues in states of South Asia are another major hurdle in the way of regional cooperation. These issues are different from state to state. In Pakistan, it is the political instability along with terrorism and extremism that halted state efforts towards meaningful regional cooperation for the last decade. In the case of Afghanistan, the Taliban factor is the most dominant one that caused a prolonged stay of NATO's troops on her soil with transitional democracy (Gaan, 2015). It combines to form an unstable Afghanistan that negates any move towards regional cooperation. Similarly, natural disasters, and Tsunami in Srilanka, Political instability, and ethnic problems in Bangladesh as in Nepal, Nepali immigrant issues in Bhutan, and religious intolerance in India are the major intrastate issues that impede regional cooperation in South Asia. While making these issues a reason for cooperation among Asian states, they never admired by thinking collectively that further worsened the situation. These intra-state issues not only made a roadblock for successful regional cooperation but also damaged the individual state capacities to cope with it. The current flows of terrorism and extremism in the whole of South Asia as well as in the individual states vividly show the failure of South Asian states and their policymaker in this regard

\section{Poor Infrastructure and Transport Issues}

Good infrastructure and excellent connectivity is the key to establishing and promoting deeper integration among the members of any regional grouping (Dash, 2008). The partner countries need to 
engage themselves in building the required physical infrastructure and communication that may easily make transport of goods and services to the destined country. In the context of the current play, SAARC countries lack both proper infrastructure and trans port facilities that cause difficulties in trade and economic integration. While sharing common features as well like cheap labor, low income, and low value-added commodities and comparative advantages in the same commodities like textile, tea, and garment, etc still the inter-regional trade is very low due to poor industrial infrastructure. Moreover, an integrated transportation system must be seen as critical for enhancing regional trade and cooperation among the SAARC member countries. Serious attention does not found in the South Asian countries that ought to be given to the construction of an integrated transport system linking road, rail, and sea in a seamless continuity (Ahmed, Kelegama, \& Ghani, 2010).

\section{SAARC Charter and General Issues}

While being the sole regional bloc in South Asia, major SAARC initiatives, such as terrorism and poverty alleviation, failed to de liver the desire results due to ineffective implementation that mark the institutional capacity deficit. Along with the institutional capacity deficit the SAARC charter by itself consists of provision which does not mandate issues of bilateral nature on the platform that contribute misery to the poor SAARC secretariat. Besides lack of political will at the high level, unnecessary formalities, and principal of unanimity limited SAARC performances throughout the last few decades. Correspondingly SAARC's secretariat apathetic conditions, red-tapism, and bureaucratic hassles at the secretariat made delay in the implementation of policies. To sum up this lethargic condition of SAARC, one cannot hope for successful regional cooperation in South Asia through the platform. It needs serious attention and political will of the member's countries to bring reforms SAARC charter by abolishing "Article X" of general provision and adhering to the principle that cooperation shall not be a subtitle for bilateral and multilateral cooperation but shall complement them (Shaheen, 2013).

\section{Prospects \\ Religious and Cultural Homogeneity}

Shared historical linkages, common languages, heritage, literature, and culture make the South Asian region one of the unique entities in the world. The commonality of lifestyle, foods, dresses, cinemas, music, sports, and religious traditions including Eid al-Fitr, Diwali, and Urs across the borders provide strong motives for regional cooperation in South Asia. Even cross-border family linkages among various states exist that create a deep sympathy among commons further facilitate a favorable environment for regional cooperation. So these patterns of shared culture and religion demand high cooperation on a regional basis that can facilitate better access and opportunity to people for harmony and religious beliefs. Alongside it also urges Pan-South Asian ethos and notion of cultural identity that can successfully promote greater economic and political integration in South Asia (Sridharan, 2014).

\section{Geographical Proximity}

Geographical proximity in terms of continental closeness or of the ocean rim is the basis for regional grouping and initiatives in the present as in the past. History reveals that it was the geographic proximity that implied more impetus for regional grouping among states rather than other factors including ideology, security, etc. In South Asia, the geographical proximity more favors regional cooperation than other regions of the world (Kumar \& Singh, 2009). All the states of this region are inter-connected by road and sea except Afghanistan that only shares borders with Pakistan. Alongside common rivers in South Asia as the Ganges, the Indus, and the Brahmaputra Rivers binds the region in a common entity. Similarly, Greater Himalaya's ranges and the Indian Ocean makes South Asia a compact region in the world (Sharma, 2009). This unique geographical attribute of the South Asian region not only eases cross-border people-to-people contacts but also pushes for greater integration in the region.

\section{Economic Opportunities}

The South Asian region provides the best grouping of states linked by common rivers, cultures, having alike colonial history, institutions infrastructure, and wealthy natural resources. It has also a market of almost 1.7 billion consumers with the rising middle class, youth, and incomes complement for regional cooperation. The convergence of macroeconomic policies of South Asian countries and the similar diversification of their economies arrays attributes for the deeper economic integration in the region along with enhanced financial gains (Kahler, 2013). Alongside high saving and investment rates, export competition between several SAARC member states, and a favorable business 
environment have reinforced the strength of these economies to take full advantage of the opportunities provided by globalization. SAFTA under SAARC and cooperation on the issue of trade and transit, energy cooperation also provides the best opportunity for further economic cooperation by decreasing trade barriers among South Asian countries.

\section{Human Resources}

This region of South Asia is rich in human resources as shown in the given table it is half of the population that is below 25 years of age.

Table 2. Country Wise Population below the Age of 25

\begin{tabular}{ll}
\hline AFGHANISTAN & $64 \%$ \\
\hline BHUTAN & $47 \%$ \\
INDIA & $46 \%$ \\
MALDIVES & $43 \%$ \\
NEPAL & $53 \%$ \\
PAKISTAN & $54 \%$ \\
SRILANKA & $39 \%$ \\
\hline
\end{tabular}

If this abundant youth potential trained with a vision of both short and long-term work requirements shall promote and enhance energy production with cheap labor and workforce. Alongside the high decline work age in the coming years shows that developed countries shall move their industries and investment towards areas cheap in labor. As South Asian economies largely depend upon remittances and the developed countries' population rising from the middle towards high-income ranges that automatically provide a handsome opportunity for expatriates (Ullah, 2017). All this will create stability and peace in the region that will enhance regional cooperation in South Asia.

\section{Natural Resources}

There are vast reserves of natural resources in this region that urge profound cooperation in terms of cross-border energy trade. Hydropower resources of Nepal and Bhutan, Gas reserves of Bangladesh, coal reserves of India and Pakistan, and a huge amount of other natural reserves that can be found in most states of South Asian countries, demands cooperation for tapping and utilizing these resources. The current high electricity demand in certain Asian countries and the potential $350 \mathrm{Gw}$ of which $80,000 \mathrm{MW}$ and $23,000 \mathrm{MW}$ e lectricity of Nepal and Bhutan require high grid integration that can only provide a safe and secure future of energy in South Asia but also cross border cooperation in the power sector (Saklani, Shrestha, Mukherji, \& Scott, 2020). The following table shows the potential coal, oil, gas, and hydro energy availability of the SAARC countries that implies high prospects of cooperation amongst them subjected to the emerging high demand.

\begin{tabular}{lllll} 
Table 3. Ene rgy & Availability of the SAARC Countries & & \\
\hline COUNTRY & $\begin{array}{l}\text { COAL } \\
\text { MILLION } \\
\text { TONNES }\end{array}$ & $\begin{array}{l}\text { OIL } \\
\text { MILLION } \\
\text { BARRELS }\end{array}$ & $\begin{array}{l}\text { GAS } \\
\text { TCF }\end{array}$ & $\begin{array}{l}\text { HYDROPOW ER } \\
\text { MW }\end{array}$ \\
& 440 & 80 & 1.75 & 25,000 \\
\hline AFGHANISTAN & 884 & 12 & 8.5 & 330 \\
BANGLADESH & 2 & 0 & 0 & 30,000 \\
BHUTAN & 90.085 & 5700 & 50 & 150,000 \\
INDIA & 0 & 0 & 0 & 0 \\
MALDIVES & NA & 0 & 0 & 42,000 \\
NEPAL & & & & (POTENTIA L \\
& 17550 & 324 & 0 & $83,000 \mathrm{MW})$ \\
PAKISTAN & NA & 150 & 0 & 2,000 \\
SRILANKA & $\mathbf{1 0 8 , 9 6 1}$ & $\mathbf{5 , 9 0 6}$ & $\mathbf{8 4 . 9 5}$ & $\mathbf{2 9 4 , 3 3 0}$ \\
TOTAL & & & &
\end{tabular}

\section{Conclusion}

South Asia, while being an ideal region for cooperation in all domains ranging from economic to scientific and cultural integration based on geographical proximity, natural and human capital, and cultural homogeneity still out of the path of regional integration. Under the premises of the Neorealist paradigm, it is the high-politic factor, ad-hoc policies, terrorism, historical mistrust, and political division that could be attributed as the palpable factors creating hurdles in the path of regional cooperation. Especially the blame game of India and Pakistan is one of the prominent factors 
that jeopardize the fate of this region as both are atomic powers. Similarly, terroris $m$ in Afghanistan and natural disasters in Bangladesh, Nepal, and Maldives also add further obstacles in achieving this objective.

To achieve the objective of regional cooperation, Pakistan and India must settle its score first. Rather than going into criticizing one another, both need to identify the underlying causes of any is sue especially the terrorist infiltration across the border. The political will of the leaders of each country is of utmost obligatory for promoting peace and cooperation. SAARC should be mandated both by India and Pakistan to make it strong and functional to reset the course of integration. Foreign developed countries including China, the USA, Germany, Japan, and Russia should be made part of SAARC as a welcome gesture.

\section{References}

Acharya, A. (1992). Regional military-security cooperation in the Third World: A conceptual analysis of the relevance and limitations of ASEAN (Association of Southeast Asian Nations). Journal of Peace Research, 29(1), 7-21.

Ahmed, S., Kelegama, S., \& Ghani, E. (Eds.). (2010). Promoting Economic Cooperation in South Asia: Beyond SAFTA. SAGE Publications India.

Bandara, J. S., \& Cai, Y. (2014). The impact of climate change on food crop productivity, food prices, and food security in South Asia. Economic Analysis and Policy, 44(4), 451-465.

Bhasin, M. (2008). India's Role in South Asia: Perceived Hegemony or Reluctant Leadership?'. Indian Foreign Affairs Journal, 3(4), 1-25.

Christensen, T. J. (2011). Worse than a monolith: Alliance politics and problems of coercive diplomacy in Asia. Princeton University Press.

Dash, K. C. (2008). Regionalism in South Asia: Negotiating Cooperation, institutional structures (Vol. 8). Routledge.

Gaan, N. (2015). Youth bulge: constraining and reshaping transition to Liberal democracy in Afghanistan. India Quarterly, 71(1), 16-36.

Garavini, G. (2012). After empires: European integration, decolonization, and the challenge from the global South 1957-1986. Oxford University Press.

Irwin, D. A. (2011). Trade policy disaster: lessons from the 1930s. MIT press.

Kahler, M. (2013). Rising powers and global governance: negotiating change in a resilient status quo. International affairs, 89(3), 711-729.

Karim, M. A. (2014). South Asian regional integration challenges and prospects. Japanese Journal of Political Science, 15(2), 299.

Kumar, R., \& Singh, M. (2009). India's role in South Asia trade and investment integration.

Murshed, M. (2021). Can regional trade integration facilitate renewable energy transition to ensure energy sustainability in South Asia? Energy Reports, 7, 808-821.

Paul, T. V., Wirtz, J. J., \& Fortmann, M. (2004). Balance of power: theory and practice in the 21st century. Stanford University Press.

Quinn, R., \& Gibson, B. (2017). An Analysis of Kenneth Waltz's Theory of International Politics. CRC Press.

Saklani, U., Shrestha, P. P., Mukherji, A., \& Scott, C. A. (2020). Hydro-energy cooperation in South Asia: Prospects for transboundary energy and water security. Environmental Science \& Policy, 114, 22-34.

Shaheen, I. (2013). South Asian Association for regional cooperation (SAARC): its role, hurdles, and prospects. IOSR Journal of Humanities and Social Science, 15(6), 01-09.

Shambaugh, D., \& Yahuda, M. (Eds.). (2014). International relations of Asia. Rowman \& Littlefield.

Sharma, N. L. (2009). INDIA AND REGIONAL INTEGRATION IN SOUTH ASIA Hope for Greater Asian Cooperation. The Indian Journal of Political Science, 907-917.

Singh, M. (2016). SAARC for geopolitical symbolism: Whither multilateralism? South Asian Survey, 23(1), 1-16.

Telò, M. (2007). Introduction: Globalization, new regionalism, and the role of the European Union. European Union and New Regionalism, 25-46.

Yadav, R. S. (2010). Regional cooperation in South Asia: a study of SAARC (Doctoral dissertation, Aligarh Muslim University). 